\title{
Self-care, sense of coherence and depression in patients hospitalized for decompensated heart failure
}

\author{
Autocuidado, senso de coerência e depressão em pacientes \\ hospitalizados por insuficiência cardíaca descompensada \\ Autocuidado, sentido de coherencia y depresión en pacientes \\ hospitalizados por insuficiencia cardiaca descompensada
}

Viviane Martinelli Pelegrino Ferreira ${ }^{1}$, Luma Nascimento Silva², Rejane Kiyomi Furuya ${ }^{3}$, André Schmidtt ${ }^{4}$ Lídia Aparecida Rossi $^{5}$, Rosana Aparecida Spadoti Dantas ${ }^{6}$

${ }^{1} \mathrm{PhD}$ Student, Fundamental Nursing Program, University of São Paulo at Ribeirão Preto College of Nursing, Ribeirão Preto, SP, Brazil.

${ }^{2}$ Master Student, Fundamental Nursing Program, University of São Paulo at Ribeirão Preto College of Nursing, Ribeirão Preto, SP, Brazil.

${ }^{3}$ Post-Doctoral Student, Department of General and Specialized Nursing, University of São Paulo at Ribeirão Preto College of Nursing, Ribeirão Preto, SP, Brazil.

${ }^{4}$ Associate Professor, Department of Internal Medicine, University of São

Paulo at Ribeirão Preto College of

Nursing, Ribeirão Preto, SP, Brazil.

5 Titular Professor, Department of General and Specialized Nursing, University of São Paulo at Ribeirão Preto College of Nursing, Ribeirão Preto, SP, Brazil.

${ }^{6}$ Associate Professor, Department of General and Specialized Nursing, University of São Paulo at Ribeirão Preto College of Nursing, Ribeirão Preto, SP, Brazil.

\section{ABSTRACT}

Objective: To analyze the self-care behaviors according to gender, the symptoms of depression and sense of coherence and compare the measurements of depression and sense of coherence according to gender. Method: A correlational, cross-sectional study that investigated 132 patients with decompensated heart failure (HF). Data were collected through interviews and consultation to medical records, and analyzed using the chi-square and the Student's $t$ tests with significance level of 0.05. Participants were 75 men and 57 women, aged 63.2 years on average $(S D=13.8)$. Results: No differences in self-care behavior by gender were found, except for rest after physical activity ( $\mathrm{p}=$ 0.017 ). Patients who practiced physical activity showed fewer symptoms of depression $(p<0.001)$. There were no differences in sense of coherence according to self-care behavior and gender. Women had more symptoms of depression than men $(p=0.002)$. Conclusion: Special attention should be given to women with HF considering self-care and depressive symptoms.

\section{DESCRIPTORS}

Heart Failure; Self Care; Sense of Coherence; Depression; Hospitalization; Nursing Care. 


\section{INTRODUCTION}

Heart failure (HF) is a chronic condition of complex treatment for involving multiple factors in its origin and evolution, as well as high socioeconomic costs ${ }^{(1)}$. It is also a public health priority and its prevalence increased over the last decade. Low cost strategies such as using electronic messages have been tested to promote adherence to selfcare behaviors in the long run without straining the health resources ${ }^{(2)}$. Achieving results of impact for patients and the health system is a major challenge for HF management.

Despite advances in the diagnosis and treatment of HF, the disease morbidity and mortality remain high. In addition, HF patients have high rates of readmissions, with about $30 \%$ of patients readmitted in a year period ${ }^{(1,3)}$, and each hospitalization adding extra weight to worsening the survival curve ${ }^{(4)}$. The HF decompensation is detrimental for both the physical as the emotional performance of patients, and contributes to a reduction in life expectancy and worsening in quality of life ${ }^{(3)}$.

In Brazil, there are about 6.5 million patients with HF. Approximately one third of these patients are hospitalized annually $y^{(1)}$. The factors related to readmission are the presence of other medical conditions, age ${ }^{(5-6)}$, inadequate left ventricular ejection fraction (LVEF), among others ${ }^{(7)}$. In 2011, there were 258,069 admissions and the mortality proportion was $9.34 \%{ }^{(8)}$, with predominance of the male gender among hospitalizations due to HF decompensation ${ }^{(9)}$.

Several factors can lead patients with HF to clinical decompensation, as the little knowledge of the syndrome and treatment, and poor adherence to self-care recommendations, which involve a diet with restricted fluid and salt intake, daily weight monitoring, physical activity and regular use of medication ${ }^{(1,10)}$. An approach focused on individuals with $\mathrm{HF}$ and aimed at the self-management of their care is essential because it can help them to feel more confident to identify and find solutions to self-care barriers ${ }^{(11)}$.

Self-care can be defined as a process of naturalistic decision-making involving the selection of behaviors that maintain physiological stability (maintenance of self-care) and the response to symptoms when they occur (self-care management). In patients with HF, several clinical, physical, psychological, situational and social aspects may affect the management of self-care, requiring that individuals change their behavior in order to cope with the disease and treatment, which can lead to psychological disorders ${ }^{(12)}$.

Depression is considered the most common mood alteration in patients with $\mathrm{HF}$, with prevalence between $9 \%$ and $60 \%$. This variation is explained by the higher condition of depression in women and cohorts of hospitalized patients, a reflex of HF decompensation and the greater severity in hospitalized patients. Despite the high rates of prevalence and incidence, depression in $\mathrm{HF}$ patients is rarely diagnosed and treated ${ }^{(13-14)}$.

Depression negatively influences the evolution of HF because it is associated with non-adherence of patients to self-care recommendations, contributing to increase readmission rates, treatment costs and mortality ${ }^{(15)}$.
The presence of depressive symptoms can lead to ineffective or even harmful coping mechanisms ${ }^{(11)}$. The sense of coherence has been defined as the use of internal resources to deal with stress and the demands of life ${ }^{(16)}$. In this sense, evaluating the sense of coherence of patients with decompensated HF enables a better understanding of how they react to the disease and treatment, expanding our knowledge of their strategies to cope with stress ${ }^{(17)}$. Patients with decompensated HF require individual adjustment in order to gradually change their lifestyles and attribute a new meaning to their situation due to the disease and treatment ${ }^{(17)}$.

Men and women with heart failure may have different experiences and therefore use different strategies to cope with the disease. Women may have a better perception of health and build more positive coping strategies than $\operatorname{men}^{(18)}$.

The development and implementation of effective strategies require identifying the profile peculiarities of $\mathrm{HF}$ patients hospitalized for decompensated clinical condition ${ }^{(9)}$. However, there are no conclusive studies considering whether the gender of patients may interfere with self-care behaviors in the presence of depressive symptoms and sense of coherence.

The presence of self-care behaviors has been associated with fewer hospitalizations due to HF decompensation. If the presence of these behaviors is associated with the stress coping ability (measured by the sense of coherence) and absence of depressive symptoms, or even if there is a difference between genders, nurses can plan the monitoring of vulnerable groups in their homes or the outpatient clinic aiming to detect the onset of depressive symptoms and promote strategies that enhance the ability to cope with stress.

Given this context, nurses may have subsidies for a better understanding of the complexity of individuals with decompensated $\mathrm{HF}$ and allow the development of actions to encourage self-care education in this group.

The guiding questions of this exploratory study are the following: Are there are differences between patients who carry out self-care behaviors for decompensated HF and those who do not, considering the variables of gender, depression and sense of coherence? Considering the variables of depression and sense of coherence, are women admitted with decompensated HF different from men?

From this perspective, this study aimed to assess the self-care behaviors in patients with decompensated HF considering gender, depressive symptoms and sense of coherence; and compare the measurements of depression and sense of coherence according to the gender of patients admitted with decompensated HF.

\section{METHOD}

\section{STUdY DESIGN AND LOCATION}

This is a cross-sectional correlational study carried out in the medical wards of two public hospitals in Ribeirão Preto, SP, Brazil. 


\section{ETHICAL ASPECT}

This study was approved by the Research Ethics Committee of the Hospital das Clínicas and the Ribeirão Preto Medical School, University of São Paulo, under HCRP No. 9236/2009. All participants received the study information verbally and in writing. The Informed Consent was signed by the researcher and every participant in two copies, one of which was given to the participants, respecting the norms of Resolution no. 466/2012 of the National Health Council.

\section{POPULATION AND SAMPLE}

The population of interest consisted of patients with decompensated HF. The data collection was carried out between July 2010 and June 2013 by non-probability consecutive sampling. During this period, 136 patients with decompensated heart failure recorded as the main medical diagnosis of hospitalization were invited to participate in the study. As four individuals refused to participate, the sample consisted of 132 patients hospitalized with decompensated HF ( $97 \%$ of total).

The inclusion criteria were adult patients (18 years or more), of both genders and hospitalized with decompensated HF in the data collection period. The exclusion criteria were the following: patients who needed any kind of surgery during the current hospitalization; those without clinical conditions to be interviewed, for example, with complaints of dyspnea, drowsiness and fatigue when approached to participate in the interview; patients without minimal ability to understand the questions of the data collection instruments (assessed by the researchers from the participants' responses to the instruments items or the participants' reports of not understanding the instruments items); or those with diagnosis of mental disorder recorded in the medical chart.

\section{Data collection instruments}

For the social, demographic and clinical characterization was used an instrument with the following variables: date of birth, gender, years of education, marital status, family monthly income, employment status, etiology of cardiomyopathy, functional class according to the New York Heart Association (NYHA), left ventricular ejection fraction (LVEF), presence of permanent pacemaker, and comorbidities (hypertension, arrhythmias, diabetes mellitus, dyslipidemia, and chronic renal failure). This instrument was used in previous studies of patients with $\mathrm{HF}$ in our research group. Face and content validity were carried out by three nurses with clinical or cardiology research experience.

The self-care behaviors for non-pharmacological measures were assessed by self-reported responses of the study participants on salt intake control (4g salt/day), fluid intake control (1.5 liters/day), weight control (weighing $1 \mathrm{x} /$ week), physical activity practice, rest after physical activity or extra effort, no smoking, influenza vaccination (previous 12 months) and health monitoring (regular follow-up in outpatient clinics or primary care units). At the end, each behavior has received yes when it was present or performed or no in the absence of such behavior. The choice of these behaviors for non-pharmacological measures was based on the literature on the subject ${ }^{(4,10-11,19)}$.

The presence of depressive symptoms was assessed by the depression subscale of the Hospital Anxiety and Depression Scale (HADS) ${ }^{(20)}$ in its version validated for Portuguese $^{(21)}$. The depression subscale has seven items measured on a scale of 0 to 3 , and the subscale range may vary from zero to 21 points. Higher values indicate the presence of more depression symptoms ${ }^{(20)}$.

To assess the sense of coherence was used the 13-items version of the Antonovsky's Sense of Coherence questionnaire ${ }^{(16)}$, in its version validated for Brazil in cardiac patients $^{(22)}$. The response scale to the questionnaire items can range from one to seven, and the sum ranges from 13 to 91 , with higher scores meaning a stronger sense of coherence.

\section{Data Analysis}

The data were processed and analyzed using the IBM Statistical Package for Social Sciences (SPSS) version 21.0 for Windows.

All data were analyzed descriptively. To evaluate the association of self-care behaviors and gender was used the chi-square statistical test or the Fisher's exact test. The Student's t test for independent samples was used to compare the means of the sense of coherence and depression according to the presence of each self-care behavior, and to compare the means of depression and sense of coherence according to gender. The significance level adopted was 0.05 .

\section{RESULTS}

The mean age of participants $(n=132)$ was 63.2 years, $56.5 \%$ were male and $59.9 \%$ were married or living with a partner. The sample had low educational level (four years of formal education on average) and the majority was not engaged in paid work (86.4\%) (Table 1).

From a clinical point of view, $54.6 \%$ were diagnosed in functional class III. The most common etiology of $\mathrm{HF}$ was chagasic (31.8\%). The mean LVEF was 35.9\%, and most had severe left ventricular dysfunction (43.9\%), indicated by LVEF less than 30\%. Eleven patients (8.4\%) had pacemaker due to bradycardia and none of them had performed cardiac resynchronization therapy. Most patients had diagnoses of hypertension (81.1\%) and arrhythmias (60.6\%) (Table 1).

In relation to the performance of self-care behaviors, the 132 study participants reported to carry out the following more frequently: health monitoring ( $n=122 ; 92.4 \%)$, absence of smoking $(\mathrm{n}=120 ; 90.9 \%)$, salt intake control $(\mathrm{n}=$ $91 ; 68.9 \%)$, influenza vaccination $(n=81 ; 65.4 \%)$, rest after physical activity or extra effort $(n=69 ; 52.3 \%)$, weight control ( $\mathrm{n}=57 ; 43.2 \%)$, fluid intake control $(\mathrm{n}=29 ; 22 \%)$ and physical activity practice $(\mathrm{n}=17 ; 12.9 \%)$. When comparing the reports of these behaviors by the gender of participants, we found a statistically significant difference only for the behavior of rest after physical activity or extra effort. Men reported performing this self-care behavior more than women (46 male patients versus 23 females; $\mathrm{p}=0.017$ ) (Table 2). 
Table 1 - Social, demographic and clinical characteristics of patients with decompensated heart failure - Ribeirão Preto, SP, Brazil, 2010-2013.

\begin{tabular}{|c|c|c|c|c|}
\hline Variable & $\begin{array}{l}N=132 \\
n(\%)\end{array}$ & $\begin{array}{l}\text { Mean } \\
\text { (SD) }\end{array}$ & Median & $\begin{array}{l}\text { Observed } \\
\text { variation }\end{array}$ \\
\hline Age (years) & & $\begin{array}{c}63.2 \\
(13.8)\end{array}$ & 64.5 & $31.6-92.5$ \\
\hline \multicolumn{5}{|l|}{ Gender } \\
\hline male & $75(56.8)$ & & & \\
\hline female & $57(43.2)$ & & & \\
\hline \multicolumn{5}{|l|}{ Marital status } \\
\hline $\begin{array}{l}\text { married/living } \\
\text { with someone }\end{array}$ & $79(59.9)$ & & & \\
\hline $\begin{array}{l}\text { single/widowed/ } \\
\text { separated }\end{array}$ & $53(40.1)$ & & & \\
\hline Years of education & & $\begin{array}{l}4.10 \\
(3.36)\end{array}$ & 4.0 & $0-17$ \\
\hline $\begin{array}{l}\text { Professional situa- } \\
\text { tion, inactive }\end{array}$ & $\begin{array}{c}114 \\
(86.4)\end{array}$ & & & \\
\hline $\begin{array}{l}\text { Family income (in } \\
\text { reais) }\end{array}$ & & $\begin{array}{c}1863.95 \\
(1044.79)\end{array}$ & 1600.00 & $\begin{array}{l}500.00- \\
6000.00\end{array}$ \\
\hline \multicolumn{5}{|l|}{ Etiology of HF } \\
\hline Chagasic & $42(31.8)$ & & & \\
\hline Idiopathic dilated & $26(19.7)$ & & & \\
\hline Ischemic & $25(18.9)$ & & & \\
\hline Hypertensive & $15(11.4)$ & & & \\
\hline Valve & $15(11.4)$ & & & \\
\hline Others & $9(6.9)$ & & & \\
\hline \multicolumn{5}{|c|}{ Functional class (NYHA) } \\
\hline I & $2(1.5)$ & & & \\
\hline II & $35(26.5)$ & & & \\
\hline III & $72(54.6)$ & & & \\
\hline IV & $23(17.4)$ & & & \\
\hline $\operatorname{LVEF}(\%)^{*}$ & & $\begin{array}{l}35.9 \\
(14.9)\end{array}$ & 32.0 & $13-71$ \\
\hline Severe $(<30)$ & $58(43,9)$ & & & \\
\hline Moderate (30-44) & $30(22,7)$ & & & \\
\hline Mild (45-55) & $19(14.4)$ & & & \\
\hline Normal $(>55)$ & $20(15.2)$ & & & \\
\hline \multicolumn{5}{|c|}{ Presence of comorbidities (\% yes) } \\
\hline Hypertension & $\begin{array}{c}107 \\
(81.1)\end{array}$ & & & \\
\hline Arrhythmias & $80(60.6)$ & & & \\
\hline Diabetes Mellitus & $48(36.4)$ & & & \\
\hline Dyslipidemia & $48(36.4)$ & & & \\
\hline $\begin{array}{l}\text { Chronic kidney } \\
\text { disease }\end{array}$ & $39(29.5)$ & & & \\
\hline $\begin{array}{l}\text { Presence of } \\
\text { pacemaker (\% yes) }\end{array}$ & $11(8.4)$ & & & \\
\hline
\end{tabular}

When investigating depressive symptoms among participants, we observed that the average obtained by the HADS depression subscale was 7.1 ( $\mathrm{SD}=4.8$; range obtained 0-18). The Student's t test for independent samples was used to compare the means of the depression subscale according to the reports of performing the self-care behaviors or not. Patients who practiced physical activity had less symptoms of depression (mean $=3.8)$ when compared with those who did not perform physical activity (mean $=7.6$ ), with statistically significant $(\mathrm{p}<0.001)$ difference between groups. For other self-care behaviors investigated, there was no statistically significant difference between the means of groups (performance or nonperformance of behavior).

Table 2 - Presence of self-care behavior in patients with decompensated heart failure according to gender - Ribeirão Preto, SP, Brazil, 2010-2013.

\begin{tabular}{lccc}
\hline Presence of self-care behavior (yes) & $\begin{array}{c}\text { Male } \\
(\mathrm{n}=75) \\
\mathbf{n}\end{array}$ & $\begin{array}{c}\text { Female } \\
(\mathrm{n}=57) \\
\mathbf{n}\end{array}$ & $\boldsymbol{p}$ \\
\hline Health monitoring & 69 & 53 & $1.00^{*}$ \\
No smoking & 68 & 52 & $0.912 \dagger$ \\
Influenza vaccination & 51 & 30 & $0.072 \dagger$ \\
Salt intake control & 48 & 43 & $0.160 \dagger$ \\
Rest after physical activity & 46 & 23 & $\mathbf{0 . 0 1 7}+$ \\
Weight control & 33 & 24 & $0.828 \dagger$ \\
Fluid intake control & 15 & 14 & $0.531 \dagger$ \\
Physical activity & 10 & 7 & $0.858 \dagger$ \\
\hline
\end{tabular}

* $\mathrm{p}$ from the Fisher's exact test; $\dagger \mathrm{p}$ from the chi-square test.

The average measure of participants' sense of coherence was $60.9(\mathrm{SD}=14.5$, range obtained 30-91). The averages of this measure were compared among groups regarding the performance or nonperformance of each behavior. However, no statistically significant difference was found in the reports of patients with decompensated HF in relation to performing or not each self-care behavior.

For symptoms of depression by gender, women with decompensated heart failure had more symptoms of depression (mean $=8.6, \mathrm{SD}=5.3)$ than men (mean $=6.0, \mathrm{SD}$ $=4.0)$, and this difference was statistically significant $(\mathrm{p}=$ 0.002). As for the sense of coherence, men and women with decompensated HF showed similar mean values (males: mean $=61.5 \mathrm{SD}=14.4$; females: mean $=60.2 \mathrm{SD}=14.8)$, with no statistically significant difference $(\mathrm{p}=0.625)$.

\section{DISCUSSION}

In our study, most patients were male, elderly and had low level of education. Clinically, the majority presented chagasic HF, severe impairment of cardiac function, were classified in NYHA class III, and had other comorbidities such as hypertension and arrhythmias. Given these characteristics, the group of patients in this study is at high risk for hospital readmissions, since they have the profile found in the literature of patients hospitalized or readmitted due to clinical HF decompensation ${ }^{(9,11)}$.

In the performance of self-care behaviors, men and women differed only in relation to rest after physical activity or extra effort, since men with HF carried out this behavior more often than women.

In the group investigated, it was found that age, gender and comorbidities were not significant determinants for selfcare maintenance in patients with $\mathrm{HF}$, a result which was also observed in a longitudinal study with this population ${ }^{(11)}$. 
However, in another study of patients with decompensated HF, the LVEF was significantly more impaired in men compared to women ( $\mathrm{p}=0.0420$, Mann-Whitney $)^{(9)}$. In this context, the greater LVEF impairment in men may be related to the higher frequency of reports of rest after physical activity or extra effort by men when compared to women.

Many factors interfere with self-care management and the decision-making ability, such as the presence of comorbidities, depression, anxiety, age-related issues, impaired cognition, sleep disturbances, poor health and problems with access to the healthcare system ${ }^{(11)}$.

Among these factors, identifying patients with $\mathrm{HF}$ at risk of developing depressive symptoms is important because such symptoms are associated with negative outcomes as the increased risk of mortality, hospitalization and worsening of symptoms related to HF, functional class and quality of life $\mathrm{e}^{(13,15)}$.

In our study, patients who practiced physical activities had fewer depressive symptoms than those who did not. In addition, women had more depressive symptoms than men.

The literature highlights that female patients with HF present more depressive symptoms ${ }^{(13-15)}$ and carry out significantly fewer coping actions as an attempt to accept their disease or as measures to improve their treatment ${ }^{(15)}$.

Furthermore, the HF treatment itself covers a certain range of behavioral and pharmacological options and may potentiate or increase depressive symptoms. On the one hand, adopting the proposed measures gives patients a sense of increased control over the disease, but on the other hand, they may that feel their lifestyle, some of their habits and interests have changed ${ }^{(15)}$.

The exact pathophysiological mechanism of the association between depression and cardiovascular dysfunction is still unclear. Depression might affect the cardiovascular system function through the autonomic immunomodulatory dysregulation, and these changes can influence the pathogenesis of diseases that affect the cardiovascular system ${ }^{(13-15)}$.

Depressive symptoms affect the functional limitations of HF. In a study considering the gender of patients with $\mathrm{HF}$, women had worse functional status than men $^{(23)}$. The number of physical symptoms that influenced the functional status was greater in women ${ }^{(23)}$.

In patients with HF, muscle fatigue and dyspnea occur during exercise and limit the performance of daily activities, reducing quality of life. However, after a period of regular physical activity, there is improvement in pulmonary ventilation/perfusion. Regular exercise has been incorporated to the non-pharmacological measures in the treatment of HF, resulting in reduced ventilatory response during exercise, improving the quality of life and prognosis, and reducing mortality and readmissions for $\mathrm{HF}$ decompensation ${ }^{(24)}$.

Moreover, physical exercise reduces symptoms of anxiety and depression, explained by increased release of hormones such as catecholamine, adrenocorticotropic (ACTH), vasopressin, endorphins, dopamine, serotonin, and the activation of specific receptors and decreased blood viscosity, providing a calming and analgesic effect and obtaining a relaxing result after exertion ${ }^{(25)}$. These effects were found in a study in which the practice of physical activity by elderly patients was associated with the decrease in depressive symptoms ${ }^{(26)}$.

Other authors emphasize the influence of depressive symptoms in self-care. The worst self-care in depressed patients with HF may be more due to difficulties with perceived control (coping), decision making and lack of motivation for self-care than resultant of learning difficulties ${ }^{(27)}$.

We found that the sense of coherence score was similar between men and women, showing that both genders have similar perception for selecting strategies to cope with HF and its treatment. The sense of coherence of the participants was not different regarding the reports of performing the self-care behaviors or not.

When assessing the factors related to the coping strategies used by patients with HF such as age, gender and functional class according to NYHA classification, it was observed that age and gender did not influence the coping strategies. Significant differences between the use of coping strategies and functional classes were not found either. According to the authors, although patients with higher NYHA classification usually experience a worse quality of life, they behave the same way regardless of the functional class $^{(18)}$. Note that these results are limited to the investigation of patients with HF classified in functional classes II and III.

Data in the literature show the sense of coherence arising as a predictor of affection in patients with HF, indicating the highest acts in sense of coherence working as a barrier to the negative emotional effects of life stress. In this way, these results show that actively promoting coping strategies in patients with $\mathrm{HF}$ should be considered a possible approach in interventions ${ }^{(18)}$. Hence, intervention programs should promote self-care and coping, including strategies to identify and provide appropriate interventions for patients with $\mathrm{HF}$ and psychological disorders ${ }^{(27)}$.

Patients with HF who present a strong sense of coherence and coping have tendency to higher life satisfaction because they are more likely to identify barriers and solutions and feel more confident to deal with the management of $\mathrm{HF}$ and self-care ${ }^{(28)}$.

A study limitation is that the self-care scale was not subjected to a validation process, even though it was based on the literature on the subject. Furthermore, in our study, most participants admitted with decompensated heart failure were classified as NYHA functional class III, which may have influenced the depressive symptoms.

\section{CONCLUSION}

Most patients admitted for clinical decompensation of HF, reported to carry out self-care behaviors for nonpharmacological measures: health monitoring, no smoking, influenza vaccination and salt intake control. Men reported the self-care behavior of rest after physical activity more often than women.

Patients who reported physical activity practice had fewer symptoms of depression compared to those who reported not practicing it. Women had more symptoms of depression 
than men. The sense of coherence score was similar between genders and there was no difference in the sense of coherence according to the reports of performing or not the self-care behaviors in patients with decompensated HF.

The study results for nursing practice indicate that although patients with HF report high rates for some of the self-care behaviors, women have reported the self-care behavior of rest less often and also had more depressive symptoms, hence were considered as high risk for readmis- sions and medical complications. Therefore, special attention should be focused on women, since $\mathrm{HF}$ is considered a chronic condition of unfavorable prognosis and disabling.

Nurses can plan the monitoring aiming at an intervention to promote appropriate self-care, which may contribute to the improvement of symptoms and health outcomes and result in minor physical limitations and better quality of life in patients with decompensated HF.

\section{RESUMO}

Objetivo: Analisar os comportamentos de autocuidado segundo o sexo, sintomas de depressão e senso de coerência e comparar as medidas de depressão e senso de coerência segundo o sexo. Método: Estudo correlacional, de corte transversal, que investigou 132 pacientes com insuficiência cardíaca (IC) descompensada. Os dados foram coletados por entrevistas e consultas aos prontuários e analisados pelos testes Qui-quadrado e t de Student, com nível de significância de 0,05. Participaram 75 homens e 57 mulheres, com média de idade de 63,2 anos (D.P.=13,8). Resultados: Não constatamos diferenças nos comportamentos de autocuidado segundo o sexo, exceto para descanso após atividade física $(p=0,017)$. Pacientes que realizavam atividade física apresentaram menos sintomas de depressão $(p<0,001)$. Não houve diferenças no senso de coerência, segundo o comportamento de autocuidado e o sexo. Mulheres apresentaram mais sintomas de depressão que os homens $(p=0,002)$. Conclusão: Deve ser proporcionada uma atenção especial às mulheres com IC considerando o autocuidado e os sintomas depressivos.

\section{DESCRITORES}

Insuficiência Cardíaca; Autocuidado; Senso de Coerência; Depressão; Hospitalização; Cuidados de Enfermagem.

\section{RESUMEN}

Objetivo: Analizar los comportamientos de autocuidado según el sexo, síntomas de depresión y sentido de coherencia y comparar las medidas de depresión y sentido de coherencia según el sexo. Método: Estudio correlacional, de corte transversal, que investigó a 132 pacientes con insuficiencia cardiaca (IC) descompensada. Los datos fueron recogidos mediante entrevistas y consultas a las fichas médicas y analizados por las pruebas Chi cuadrado y t de Student, con nivel de significación de 0,05. Participaron 75 hombres y 57 mujeres, con promedio de edad de 63,2 años (D.P.=13,8). Resultados: No hemos constatado diferencias en los comportamientos de autocuidado según el sexo, excepto para descanso luego de actividad física $(p=0,017)$. Pacientes que realizaban actividad física presentaron menos síntomas de depresión $(p<0,001)$. No hubo diferencias en el sentido de coherencia, según el comportamiento de autocuidado y el sexo. Las mujeres presentaron más síntomas de depresión que los hombres $(p=0,002)$. Conclusión: Se les debe proporcionar una atención especial a las mujeres con IC considerando el autocuidado y los síntomas depresivos.

\section{DESCRIPTORES}

Insuficiencia Cardíaca; Autocuidado; Sentido de Coherencia; Depresión; Hospitalización; Atención de Enfermería.

\section{REFERENCES}

1. Bocchi EA, Braga FGM, Ferreira SMA, Rohde LEP, Oliveira WA, Almeida DR, et al.; Sociedade Brasileira de Cardiologia. III Diretriz Brasileira de Insuficiência Cardíaca Crônica. Arq Bras Cardiol. 2009;93(1 Supl.1):3-70.

2. Nolan RP, Payne AY, Ross H, White M, D'Antono B, Chan S, et al. An internet-based counseling intervention with email reminders that promotes self-care in adults with chronic heart failure: randomized controlled trial protocol. JMIR Res Protoc. 2014;3(1):e5.

3. Barretto ACP, Carlos Carlo CHD, Cardoso JN, Morgado PC, Munhoz RT, Eid MO, et al. Hospital readmissions and death from heart failure: rates still alarming. Arq Bras Cardiol. 2008;91(5):335-41.

4. Jessup M, Abraham WT, Casey DE, Feldman AM, Francis GS, Ganiats TG, et al. 2009 focused update: ACCF/AHA Guidelines for the diagnosis and management of heart failure in adults: a report of the American College of Cardiology Foundation/American Heart Association task force on practice guidelines: developed in collaboration with the International society for heart and lung transplantation. Circulation. 2009;119(14):1977-2016.

5. Eastwood CA, Howlett JG, King-Shier KM, McAlister FA, Ezekowitz JA, Quan H. Determinants of early readmission after hospitalization for heart failure. Can J Cardiol. 2014;30(6):612-18.

6. Frigola-Capell E, Comin-Colet J, Davins-Miralles J, Gich-Saladich I, Wensing M, Verdú-Rotellar JM, et al. Trends and predictors of hospitalization, readmissions and length of stay in ambulatory patients with heart failure. Rev Clin Esp (Barc). 2013;213(1):1-7.

7. Mazza A, Bendini MG, Leggio M, Riva U, Ciardiello C, Valsecchi S, et al. Incidence and predictors of heart failure hospitalization and death in permanent pacemaker patients: a single-centre experience over medium-term follow-up. Europace. 2013;15(9):1267-72.

8. Brasil. Ministério da Saúde. DATASUS. Informações de Saúde. Sistema de Informações Hospitalares do SUS (SIH/SUS). Morbidade hospitalar do SUS [Internet]. Brasília; 2012 [citado 2014 jul. 17]. Disponível em: http://tabnet.datasus.gov.br/cgi/sih/midescr.htm

9. Margoto G, Colombo RCR, Gallani MCBJ. Clinical and psychosocial features of heart failure patients admitted for clinical decompensation. Rev Esc Enferm USP [Internet]. 2009 [cited 2014 nov. 17];43(1):44-53. Available from: http://www.scielo.br/pdf/reeusp/v43n1/en_06.pdf

10. Riegel B, Moser DK, Anker SD, Appel LJ, Dunbar SB, Grady KL, et al. State of the science: promoting self-care in persons with heart failure: a scientific statement from the American Heart Association. Circulation. 2009;120(12):1141-63. 
11. Goodman H, Firouzi A, Banya W, Lau-Walker M, Cowie MR. Illness perception, self-care behaviour and quality of life of heart failure patients: a longitudinal questionnaire survey. Int J Nurs Stud. 2013;50(7):945-53.

12. Riegel B, Lee CS, Dickson VV. Self-care with chronic heart failure. Nat Rev Cardiol. 2011;8(11):644-54.

13. Wallenborn J, Angermann CE. Comorbid depression in heart failure. Herz. 2013; 38(6):587-96.

14. Kao CW, Chen TY, Cheng SM, Lin WS, Friedmann E, Thomas SA. Gender differences in the predictors of depression among patients with heart failure. Eur J Cardiovasc Nurs. 2013;13(4):320-8.

15. Montes Pena F, Amorim A, Fassbender C, Oliveira RFJ, Faria CAC. Insuficiência cardíaca e depressão: uma associação com desfechos negativos. Insuf Card. 2011;6(4):170-8.

16. Antonovsky A. Unraveling the mystery of health. São Franscisco: Jossey-Bass; 1987.

17. Dantas RAS, Ciol MA, Motzer SA. The association between sense of coherence and quality of life in subjects with cardiac disease. In: Lee AV, editor. Coping with disease. Nova York: Nova Science; 2005. p. 1-22.

18. Nahlén C, Saboonchi F. Coping, sense of coherence and the dimensions of affect in patients with chronic heart failure. Eur J Cardiovasc Nur. 2010;9(2):118-25.

19. Bocchi EA, Marcondes-Braga FG, Bacal F, Ferraz AS, Albuquerque D, Rodrigues DA, et al. Atualização da diretriz brasileira de insuficiência cardíaca crônica - 2012. Arq Bras Cardiol. 2012;98(1Supl.1):1-44.

20. Zigmond AS, Snaith RP. The hospital anxiety and depression scale. Acta Psychiatr Scand. 1983;67(6):361-70.

21. Botega NJ, Pereira WA, Bio MR, Garcia Júnior C, Zomignani MA. Psychiatric morbidity among medical in-patients: a standardized assessment (GHQ-12 and CIS-R) made by 'lay' interviewers in a Brazilian hospital. Soc Psychiat Epidemiol.1995;30(3):127-31.

22. Dantas RAS, Silva FS, Ciol MA. Psychometric properties of the Brazilian Portuguese versions of the 29- and 13-item scales of the Antonovsky's Sense of Coherence (SOC-29 and SOC-13) evaluated in Brazilian cardiac patients. J Clin Nurs. 2014;23(1-2):156-65.

23. Song EK, Moser DK, Lennie TA. Relationship of depressive symptoms to the impact of physical symptoms on functional status in women with heart failure. Am J Crit Care. 2009;18(4):348-56.

24. Moraes RS, Nóbrega ACL, Castro RRT, Negrão CE, Stein R, Serra SM, et al. Diretriz de Reabilitação Cardíaca. Arq Bras Cardiol. 2005;84(5):431-40.

25. Cheik N, Reis I, Heredia RAG, Ventura ML, Tufik S, Antunes HKM, et al. Efeitos do exercício físico e da atividade física na depressão e ansiedade em indivíduos idosos. R Bras Ci Mov. 2003;11(3):45-52.

26. Lee H, Lee JA, Brar JS, Rush EB, Jolley CJ. Physical activity and depressive symptoms in older adults. Geriatr Nurs. 2014;35(1):37-41.

27. Hwang B, Moser DK, Dracup K. Knowledge is insufficient for self-care among heart failure patients with psychological distress. Health Psychol. 2014;33(7):588-96.

28. Goodman H, Firouzi A, Banya W, Lau-Walker M, Cowie MR. Ilness perception, self-care behaviour and quality of life of heart failure patients: a longitudinal questionnaire survey. Int J Nurs Stud. 2013;50(7):945-53.

Financial Support: Fundação de Amparo à Pesquisa do Estado de São Paulo - FAPESP. Process number 2010/10006-8. 